\title{
The Effect of Self-Efficacy on Auditor Performance with Motivation as Mediation
}

\author{
I Made Andika Pradnyana Wistawan ${ }^{1}$ Ni Nyoman Sri Rahayu Damayanti ${ }^{2}$ \\ 1. Accounting Department, Faculty of Economics \& Business, Udayana University, Indonesia \\ 2. Accounting Department, Faculty of Economics, Warmadewa University, Indonesia
}

\begin{abstract}
Performance usually associated with an attitude of person at work to achieve organizational goals. Republic of Indonesia Financial Audit Agency (BPK RI) has an important role in realizing the implementation of a clean and free state of Corruption Collusion and Nepotism. This is done by checking the management and responsibility of state finance freely and independently. The audit quality will depend on the performance of auditor itself. The performance of an auditor is influenced by characteristics of the auditor's personality. Selfefficacy is a personality trait that refers to someone's belief that the person is able to complete his task well. Selfefficacy can affect the level of motivation, persistence and performance of employees when making an assignment. Motivation as a driver for someone to take an action has an important role to spur person to work more effective and efficient in order to achieve organizational goals. This will affect the performance of the person as well as the performance of the organization. This study was conducted at BPK RI Representative of Bali Province with the respondents is auditor who have worked more than or equal to 1 year. Hypothesis testing is carried out using path analysis techniques. The results obtained that self-efficacy has an effect on auditor performance while motivation does not have a significant effect on performance. Self-efficacy has a significant effect on auditor motivation. Based on these results the motivation was not able to mediate the influence of the relationship between self-efficacy and the performance of the auditor of BPK RI Representative of Bali Province
\end{abstract} Keywords: Self-efficacy, Motivation, and Performance.

DOI: $10.7176 /$ RJFA/10-24-19

Publication date: December $31^{\text {st }} 2019$

\section{Introductions}

Performance is one of the achievement benchmarks for an individual or an organization. Performance is usually associated with one's attitude in doing the works to achieve the purpose of the organization. This is considered as an important issue in an organization, because performance describes the productivity of someone (Cook, 2008). Republic of Indonesia Financial Audit Agency or Badan Pemeriksa Keuangan Republik Indonesia (BPK $\mathrm{RI})$ has an important role in organizing a country which is free from corruption, colusion and nepotism (UU RI No. 15 Year 2006). This role is manifested by examining the management and responsibility of the state finances freely and independently. The quality of the audit depends on the performance of the relevant BPK auditor.

The importance of auditor's role steals the attentions of the people. BPK RI has a responisibility in supervising the management and applications of the rights and the obligations of the country through calculating the money, and other parameters which are owned by the state (Rule of BPK RI No. 1 Year 2017). BPK RI of Bali Province has responsibilities in checking the financial management of the government agencies around Bali Province. In 2012, Ministry of Religion officials abused APBN funds in 2011 and 2012 when carrying out the procurement of Quran and IT Laboratory projects (www.kpk.go.id). In 2013, two staffs of Regional Human Resources Agency or Badan Kepegawaian Daerah (BKD) of Bali Province were appointed as suspects of corruption in the enrollment of CPNS in Badung District (www.okezone.com). The rising cases which have occured in government agencies requires the auditor to work more optimally to be able to detect such irregularities. The better the auditor's ability to detect irregularities in the financial statements of government institutions, the better the performance will be.

The performance of auditor is mainly influenced by the personality itself. This plays an important role in giving the satisfactions and maintaining a good health of the auditors (Krcmar, 2006). Personality absolutely affects the performance of someone in doing his work (Abdullah et al, 2013). Self-efficacy is also believed to influence the performance. Self-efficacy refers to someone's belief that the person concerned is able to complete his task well, diligently, and is able to achieve the targets. In difficult situations, individuals with low self-efficacy tend to give 
up easily, while those with high self-efficacy will try harder to overcome existing challenges (Noviawati, 2016). This will contribute to improving individual performance which will affect the organizational performance. Studies conducted by Engko (2008) and Chasanah (2008) show that there is a positive relationship between selfefficacy and performance. This is oppositely associated with the study by Noviawati (2016) resulting in the dissociation between the self-efficacy and performance.

Self-efficacy is one of the characteristics needed at the employee level and can be considered as motivation and perseverance of employees when learning to do difficult tasks (Lunenburg 2011). Individuals with these kinds of personalities tend to do more in overcoming challenges at work (Noviawati, 2016). If someone has a high level of trust, then the individual will have a higher motivation to do business in order to achieve the goals. Schunk (1995) states that self-efficacy is used to predict one's motivation.

Motivation is an encouragement for someone to do something from within. When one has a high level of motivation, then he will have the encouragements and desires to do the work. Richard (2014) states that motivation has an important role in organizing the employees to work effectively and efficiently according to their positions. The high-motivated-individual will perform better in work tham the low-motivated-individual. This will directly influence the productivity of the employees in their works (Waiyaki, 2017).

Luthan (2014:338) states that self-efficacy refers to confidence about their own ability to motivate the cognitive resources and the actions needed in order to get the job done. Manulang (2011) states that working motivation is something which encourages somoene to work better. Self-motivation helps the person to do the job effectively and efficiently and it affects the performance as well. This illustrates that self-efficacy has an indirect effect on performance with motivation as a mediating variable. Based on the background, the formulation of the problem is as follows.

\section{Literature Review}

\subsection{Personality Theory}

Personality theory states that one can predict how the others will act based on the personality. This theory shows that behavior can be determined by one's personality (Feist and Feist, 2009: 430). Alwisol (2009) states that personality is a general trait in the form of thoughts, activities, and feelings that affect systemically the overall behavior of a person. This study discusses the personality theory used to explain the effect of self-efficacy on auditor performance with motivation as an intervening variable. A person's behavior will be influenced by the nature of his personality, as well as in this study, the performance is positioned as a behavior that will later be influenced by self-efficacy and motivation which is positioned as personality traits. The nature of one's personality determines the way the individual behaves.

\subsection{Self-efficacy}

Self-efficacy is the belief that one can handle the situation and deliver positive outcomes (Bandura, 1993). An individual with this kind of personality can decide the purpose for himself in a working situation and predict how much efforts should be given to achieve the goals. Self-efficacy leads to beliefs about one's ability to bring the motivation, sources of awareness, and a series of actions needed to deal with the situation. Several studies have proven that self-efficacy is related to the way individuals perform self-control, resistance to failure, seek effective problem solving, and make efforts to complete their tasks (Bandura, 1986) in (Cherian and Jacob, 2013). Individuals with high self-efficacy will have good job performance and satisfaction compared to individuals with low self-efficacy.

\subsection{Motivation}

Hamzah (2011:71) divides the motivation into two definitions; conceptually and operationally. Conceptually, working motivation is defined as one of the factors influencing the performance of someone. The size or effect of motivation on one's performance depends on how much intensity the motivation is given. Operationally, work motivation is defined as the drive from inside and outside of a person to do something that is visible from the internal and external dimensions. A person's motivation depends on the strength of the motive. Maduka and Okafor (2014) state that motives can be in the form of individual needs and desires. The motive will encourage someone to act which will determine the behavior in question. Individuals with a high level of motivation will increase company productivity. This is because the person concerned can work more effectively and efficiently 
so as to produce good performance. Motivation is an important aspect in doing a good job doing work individually or in groups.

\subsection{Performance}

Cook (2008) argues that the performance of an individual is very crucial because it influences the productivity of an organization. The assessment to this aspect can be seen from the way someone manage the tasks and his desire to advance in his field of working. The auditor's performance is a result of the work achieved according to the responsibility given to him, and becomes one of the parameters used in defining the outcomes. Trisnaningsih (2007) states that performance can be measured by paying attention to quality, namely the quality of work produced; quantity, namely the amount of work produced in a certain period of time; and timelines. Wright (1980) states that there are four aspects to measure auditor performance, namely technical and analytical skills, interpersonal skills, communication skills, and professional characteristics.

\subsection{The Effects of Self-efficacy in Auditor's Performance of BPK RI of Bali Province}

Luthan (2014:338) states that self-efficacy refers to confidence about their own ability to motivate the cognitive resources and the actions needed in order to get the job done. Auditors with high level of self-efficacy will have the belief and confidence that they can finish the work successfully. Auditors with this kind of nature have high level of initiative in solving problems. This results in the optimal work of the auditors. If the auditor can do his work more optimally, then this will directly contribute positively to his performance. This statement is strengthened by research conducted by Chasanah (2008) which found that self-efficacy has a positive effect on performance. Based on the above description, the following hypothesis can be formulated:

H1: Self-efficacy has a significant effect on the performance of auditors of the Republic of Indonesia Financial Audit Agency (BPK RI) Representative of Bali Province.

\subsection{The Effects of Motivation in The Auditor's Performance at BPK RI of Bali Province}

Motivation is one of the crucial aspects for an individual to stay persistent in their work inside the organization. Motivation helps someone to achieve the goals of the organization (Omollo, 2015). Ibrahim and Brobbey (2015) state that motivation is a power which push people to behave properly in order to achieve success. High motivational people will encourage themselves in doing the jobs effectively and efficiently. This will provide great productivity and results to the auditor's work.

$\mathrm{H}_{2}$ : Motivation significantly influences the performance of auditors of the Republic of Indonesia Financial Audit Agency (BPK RI) Representative of Bali Province.

\subsection{The Effects of Self-efficacy in The Auditor's Motivation at BPK RI of Bali Province}

Self-efficacy is a personality trait that describes an individual's self-confidence in his abilities. Individuals with high self-efficacy will have a higher urge to complete their work. In addition, these individuals have better ability to do work with a high level of difficulty and have good ability in solving problems. This will affect his motivation when working (Zimmerman, 2000). Auditors who have high self-efficacy properties will have a higher commitment to completing their work properly. The higher the commitment that is owned, the higher the motivation that the auditor will have (Cherian and Jacob, 2014). Based on the above description, the following hypothesis can be formulated:

$\mathrm{H}_{3}$ : Self-efficacy has a significant effect on the motivation of auditors of the Republic of Indonesia Supreme Audit Agency (BPK RI) Representative of Bali Province.

\subsection{The Effect of Self Efficacy in The Auditor's Performance at BPK RI of Bali Province through Motivation}

Individuals with high self-efficacy level are more determined in doing the works, have lesser doubts and always seek for activities and new challanges (Wood and Bandura, 1989). Auditors with a high level of self-efficacy will have the confidence that they are able to complete their work successfully and better. This self-confidence will motivate the auditor to be more optimal in terms of completing work that will have a positive effect on his work. If an audit is able to provide good work in the form of a quality audit report, it will directly affect its performance. Judge and Bono (2003) state that motivation is able to mediate the effect of self-efficacy on performance. 
$\mathrm{H}_{4}$ : Self-efficacy has a significant effect on the performance of auditors of the Republic of Indonesia Supreme Audit Agency (BPK RI) Representative of Bali Province through motivation.

\section{Research Methodology}

\subsection{Population and Samples of The Research}

The population of this research was the auditors who worked at BPK RI Representative of Bali Province. This study used saturated sample technique, which included the entire population as a sample that is as much as 110 auditors.

\subsection{Operational Variable and Variable Measurement 3.2.1 Auditor Performance (Y)}

Auditor performance is one of the ways used by auditors in a certain period of time that uses certain measurements (standards) (Trisnaningsih, 2007). Wright (1980) states that there are four aspects to measure auditor performance, namely technical and analytical skills, interpersonal skills, communication skills, and professional characteristics. Auditor performance measurement is done by using a questionnaire adapted from Wright's (1980) research and the Supreme Audit Agency Regulation (2007) which consists of 13 questions relating to the capabilities of the auditor.

\subsubsection{Self-efficacy $\left(\mathrm{X}_{4}\right)$}

Self-efficacy is confidence of a user that allows him to carry out tasks at a certain level. This is one of the personal influencing factors to achieve the task (Bandura, 1993). Measurement of the nature of uses a questionnaire adapted from the research of Judge et al (1998) in Oyler (2007). It can be seen that there are 7 items of statements relating to individual beliefs about their ability to complete a task or job.

\subsubsection{Motivation}

Motivation is something that starts a movement, something that makes people do certain things (Armstrong, 1994 in Trisnaningsih, 2001). Budget measurement uses the theory of Abraham Maslow in the book Robbins and Judge (2008: 224) which consists of five aspects, namely the need for physiology, sense of security, social, respect, and self-actualization.

\subsection{Data Analysis Method}

Data collection methods used in this study was survey method with questionnaire techniques. First of all the Method of Succesive Interval (MSI) was carried out on the answers to the questionnaires that have been filled in by the respondents. The MSI process was carried out to transform ordinal data (questionnaire scores) into interval data. After that, the research instrument was tested by testing the validity and reliability. If the correlation coefficient is at least 0.3 then the instrument has been declared valid. If Cronbach's alpha is more than 0.60, it means that the instrument used is reliable (Nunnally, 1960 in Ghozali, 2009: 46). The next analysis is to test the hypothesis by using multiple linear regression analysis.

\section{Result And Discussion 4.1 Description of The Respondents}

Based on the data obtained, most of the respondents were female. The majority of the respondents aged between 31 to 40 years old. There were 16 respondents who finished undergraduate study and 6 respondents who finished graduate study. All of the respondents had followed an auditor training. Most of the auditors had worked for more than 5 years.

\subsection{Result of The Instrumental Test}

All of the instruments are valid with correlation coefficient values greater than 0.3. A variable is considered reliable if the value of cronbach's alpha is greater than 0.60 . The instrument has also been reliable with the cronbach's alpha value of each variable of self-efficacy, motivation, and performance of $0.937 ; 0,843 ;$ and 0.844 . 


\subsection{Classical Assumption Test Results}

Data has been freed from multicollinearity problems with tolerance self-efficacy and motivation values above 0.1 ie 0.862 and 0.862 . VIF values of self-efficacy and motivation were less than 10 , which were 1,160 and 1,160. Data distribution was normal with asymp.sig (2-tailed) value of 0.620 . Heteroscedasticity test was done by Glejser test, which is to regression the residual absolute value from the model estimated on the independent variable. If the level of significance obtained is greater than the alpha level $(0.05)$ used, then the regression model is said to contain no heteroscedasticity problem. Test results show that self-efficacy and motivation $(0.675 ; 0.140)$ have a significance level above 0.05 .

\subsection{Results of Multiple Linear Regression Analysis}

The value of $\mathrm{R}$ Square is 0.328 . This means that $32.8 \%$ of auditor performance variables are influenced by selfefficacy and motivation used in this study. While $67.2 \%$ is influenced by other variables not examined in this study. $\mathrm{F}$ test is done by looking at the significance value in the ANOVA table, if the significance value is $\mathrm{F} \leq \alpha$ $(0.05)$, then this model is said to be feasible or the independent variable is able to explain the dependent variable. Therefore the test results show a significance value of 0.023 so it can be concluded that this model is said to be feasible to study.

\section{Results of Hypothesis Test}

\subsection{The Effect of Self-Efficacy in The Auditor's Performance of BPK RI Respresentative of Bali Province}

The results of data analysis showed that self-efficacy had a significant effect on performance with a significance value of 0.026 . Luthan (2014: 338) states that self-efficacy refers to self-confidence about someone's ability to motivate cognitive resources and actions needed to succeed in carrying out certain tasks. Auditors with a high level of self-efficacy will have the confidence that they are able to complete their work successfully and better. Based on the description of respondents, the auditors also have all participated in audit training. This makes the auditor gain more knowledge to carry out audits that will contribute to the performance of the relevant when conducting an audit. The results of this study are supported by Chasanah (2008) who also found that selfefficacy has a positive effect on performance.

The results of data analysis showed that self-efficacy had a significant effect on performance with a significance value of 0.026 . Motivation has no significant effect on performance with a significance value of 0.665 while self-efficacy has a significant effect on motivation with a significance value of 0.022 .

\subsection{The Effect of Motivation in Auditor's Performance of BPK RI Representatives of Bali Province}

Motivation does not play a significant role in performance with a significant value of 0.665 . High level of motivation will encourage someone to do more in his work. The definition of operational variable of motivation in this study is something which direct people to behace in certain ways (Armstrong, 1994 in Trisnaningsih, 2001). Although the auditors have good motivation, if they are not followed by a high internal locus of control, then it does not contribute to someone's actions when doing a job. This will affect the performance that will be provided by the auditor while working.

\subsection{The Effect of Self Efficacy in Auditor's Motivation of BPK RI Representatives of Bali Province}

Self-efficacy has a significant effect on motivation with a significance value of 0.022 . The auditors mostly have a service period of more than 5 years. this illustrates that those who fear have good experience and good understanding related to the implementation of the audit. Auditors with a high level of experience will also have high level of confidence to do an action well. These individuals have better ability to do work with a high level of difficulty and have good ability in solving problems. This will affect his motivation when working (Zimmerman, 2000). Auditors who have high self-efficacy properties will have a higher commitment to completing their work properly. The higher the commitment that is owned, the higher the motivation that the auditor will have (Cherian and Jacob, 2014). 
5.4 The Effect of Self-Efficacy in Auditor's Performance of BPK RI Representatives of Bali Province through Motivation

Self-efficacy variable (X1) directly affects the performance $(\mathrm{Y})$ as many as 0.834 and indirectly affects the performance with a value of 0.652 ; hence, the total value of self-efficacy's effect towards the performance is 1.48. Despite the result, motivation does not have a significant association with the performance, thus further research could not be conducter. Motivation cannot act as a mediating variable in the effect of self-efficacy on performance. Self-efficacy has a direct and indirect influence on performance through motivation. However, in this research motivation does not have a significant effect on performance so that motivation is not able to mediate the relationship of self-efficacy and performance of an auditor. This happens of the low internal locus of control; hence, even though they have good motivation but not accompanied by a high internal locus of control, it will have an adverse effect on performance.

\section{Conclusions And Suggestions 6.1 Conclusion}

The results showed that self-efficacy had a significant effect on auditor performance, while motivation had no significant effect on auditor performance. Self-efficacy had a significant effect on motivation. The results also prove that motivation is not able to mediate the effect of self-efficacy and performance.

\subsection{Suggestion}

Subsequent research is recommended to use the auditor with the functional examiner of the middle and primary as a respondent. That position is an audit quality controller who is considered to know the performance of the first and young auditor as the executor of the audit task. This method is considered capable of providing more objective results compared to self-rated measures.

\section{Reference}

Alwisol. 2009. Psikologi Kepribadian Edisi Revisi. Malang: UMM Press.

Bandura, A. 1993. Perceived Self-Efficacy in Cognitive Development and Functioning. Educational Psychologist, Vol. 28: 117-148.

Chasanah, Nur. 2008. "Analisis Pengaruh Empowerment, Self-Efficacy dan Budaya Organisasi Terhadap Kepuasan Kerja Dalam Meningkatkan Kinerja Karyawan (Studi Empiris pada Karyawan PT. Mayora Tbk Regional Jateng dan DIY)", (tesis). Semarang: Universitas Diponegoro.

Cherian J. dan Jacob J.2013. Impact of Sef Efficacy on Motivation and Performance of Employees. International Journal of Business and Management, Vol. 8: 80-88.

Cook, A. L. 2008. "Job Satisfaction and Job Performance: Is The Relationship Spurious" (tesis). Texas: Texas A\&M University.

Engko, C. 2008. Pengaruh Kepuasan Kerja Terhadap Kinerja Individual Dengan Self Esteem dan Self Efficacy Sebagai Variabel Intervening. Jurnal Bisnis dan Akuntansi, Vol. 10: 1-12.

Feist, Jess dan Feist, Gregory J. 2009. Theories of Personality. Amerika Serikat: McGraw Hill

Ghozali, Imam. 2009. Aplikasi Analisis Multivariate dengan Program SPSS. Edisi Kedua. Semarang: Universitas Diponegoro.

Hamzah B. U. 2011. Teori Motivasi dan Pengukurannya: Analisis di Bidang Pendidikan. Jakarta: Bumi Aksara.

Ibrahim M. dan Brobbey V. A. 2015. Impact of Motivation on Employee Performance, The Case of Some Selected Micro Finance Companies in Ghana. International Journal of Economics, Commerce and Management, Vol VIII: 1218-1236.

Judge T.A. dan Bono J. E. 2003. Core Self-Evaluations: A Review of the Trait and its Role in Job Satisfaction and Job Performance. European Journal of Personality, Vol. 17: 5-18.

Jurnal Nasional. 2010. Korupsi Al quran, KPK Periksa Tiga Pejabat Kemenag. http:// www.kpk.go.id. 16 Maret $2018(14: 30)$.

Krcmar, Andrea M. 2006. "The Effect of Personality on Adults Perceived Benefit of Speech therapy: A Pilot Study" (tesis). United State of America: University of Maryland.

Lunenburg, F. C. 2011. Goal Setting Theory of Motivation. International Journal Of Management, Business and Administration, Vol. 15:1-6.

Luthans, F. 2014. Organization Behavior. New York: McGraw Hill International.

Maduka C. E. dan Okafor O. 2014. Effect of Motivation on Employee Productivity: A Study of Manufacturing Companies in Nnewi. International Journal of Managerial Studies and Research, Vol. 2: 137-147. 
Manulang M. 2011.Manajemen Personalia. Jakarta: Aksara Baru.

Noviawati, D. R.,2016. Pengaruh Self Efficacy Terhadap Kinerja Karyawan Dengan Motivasi Sebagai Variabel Intervening (Studi Pada Karyawan Divisi Finance dan Divisi Human Resource PT. Coca-Cola Distribution Indonesia, Surabaya). Jurnal Ilmu Manajemen. Vol. 4:1-12.

Omollo P. A. 2015. Effect of Motivation on Employee Performance of Commercial Banks in Kenya: A Case Study of Kenya Commercial Bankin Migori County. International Journal of Human Resource Studies, Vol 5: 87-103.

Oyler, J. D. 2007. "Core Self-Evaluations and Job Satisfaction: The Role of Organizational and Community Embeddedness", (disertasi). Virginia: Virginia Polytechnic Institute and State University.

Peraturan Badan Pemeriksa Keuangan Republik Indonesia Nomor 01 Tahun 2007. 7 Maret 2007. Lembaran Negara Republik Indonesia Tahun 2007 Nomor 4707. Jakarta.

Richard,B. 2014. “The Effect of Motivation on Employees' Performance: Empirical Evidence From The Brong Ahafo Education Directorate", (tesis). Ghana: Kwame Nkrumah University of Science and Technology.

Robbins S. P. dan Judge T. A. 2008. Perilaku Organisasi Edisi ke-12. Jakarta: Salemba Empat.

Schunk, D. H. 1995. Self-Efficacy, Motivation, and Performance. Journal of Applied Sport Psychology, Vol. 7:112-137.

Trisnaningsih, S. 2007. Independensi Auditor dan Komitmen Organisasi Sebagai Mediasi Pengaruh Pemahaman Good Governance, Gaya Kepemimpinan dan Budaya Organisasi Terhadap Kinerja Auditor. Simposium Nasional Akuntansi X. Makassar, 26-28 Juli.

Undang-Undang Republik Indonesia Nomor 15 Tahun 2006 Badan Pemeriksa Keuangan. 30 Oktober 2006. Lembaran Negara Republik Indonesia Tahun 2006 Nomor 85. Jakarta.

Waiyaki, E.W.2017. "Effect of Motivation on Employee Performance: A Case of Pam Golding Properties Limited, Nairobi" (tesis). Nairobi: United States International University.

Wood, R. dan Bandura, A. 1989. Social Cognitive Theory of Organizational Management. Academy of Management Review, Vol. 14: 361-384.

Wright. A. 1980. Performance Appraisal of Staff Auditors. The CPA Journal, Vol. 50: 37-43. 